\title{
MICROSTRUCTURE OF BRAZED JOINTS OF NICKEL ALUMINIDE
}

\author{
S.V. MAKSYMOVA, V.F. KHORUNOV, V.V. MYASOED, V.V. VORONOV and P.V. KOVALCHUK \\ E.O. Paton Electric Welding Institute, NASU
}

11 Bozhenko Str., 03680, Kiev, Ukraine. E-mail: office@paton.kiev.ua

\begin{abstract}
Intermetallic alloys on the base of $\mathrm{Ni} 3 \mathrm{Al}$ and $\mathrm{NiAl}$ phases belong to the new class of challenging casting structural materials. Application of Ni3Al-based materials allows increasing the service life of parts by 3-4 times, working temperatures of turbine inlet gas by $50-100{ }^{\circ} \mathrm{C}$, reducing the mass of turbines and, as a consequence, increasing their specific thrust and efficiency. The wide application of alloys on $\mathrm{Ni}_{3} \mathrm{Al}$ base in industry requires the development of technological processes of producing permanent joints, including method of brazing, as the alloys, containing a high percent of $\gamma^{\prime}$-phase, are referred to the class of hard-to-weld ones due to possible crack formation. At present, the nickel brazing filler alloys (BFA), containing silicon and boron as depressants, are used for brazing high-temperature high-alloy nickel alloys, thus leading to formation of brittle phases (silicides, borides) in joints, having a negative influence on fatigue life. Their elimination is connected with long-time conditions of heat treatment or almost impossible. The present work shows the possibility of application of eutectic BFA on nickel base, not containing boron and silicon. The results of metallographic examinations and X-ray spectral microanalysis of brazed joints of intermetallic alloys on the base of $\gamma^{\prime}$-phase $\left(\mathrm{Ni}_{3} \mathrm{Al}\right)$ are given. Shown are the morphological peculiarities of structure formation of brazed joints, produced by high-temperature vacuum brazing and BFA on base of $\mathrm{Ni}-\mathrm{Cr}-\mathrm{Zr}$ and $\mathrm{Ni}-\mathrm{Co}^{-} \mathrm{Cr}-\mathrm{W}-\mathrm{Mo}-\mathrm{Al}-\mathrm{Nb}-\mathrm{B}$ systems. 7 Ref., 3 Tables, 15 Figures.
\end{abstract}

Key words: intermetallic alloys, nickel aluminides, vacuum brazing, brazing filler alloy, brazed seam, spreading tests, microstructure, X-ray spectral microanalysis

Intermetallic alloys on the base of $\mathrm{Ni}_{3} \mathrm{Al}$ and $\mathrm{NiAl}$ phases belong to the new class of challenging casting structural materials, containing a large amount of $\gamma^{\prime}$-phase and being a real alternative to metallic materials of the high-temperature application. Intermetallics $\mathrm{Ni}_{3} \mathrm{Al}$ and $\mathrm{NiAl}$ are characterized by an ordered crystalline lattice, that provides them a complex of high physical-mechanical properties, such as increased stability at temperatures up to $1200-1300{ }^{\circ} \mathrm{C}$, decreased density (7.3 and $5.9 \mathrm{~g} / \mathrm{cm}^{3}$, respectively), high modulus of elasticity and resistance to oxidation. This opens up the wide prospects of their application under high-temperature conditions, allows decreasing the mass of designed structures and increasing their coefficient of efficiency [1-5]. To widen the application of alloys on $\mathrm{Ni}_{3} \mathrm{Al}$ base in industry, it is necessary to develop technological processes of producing permanent joints including brazing, as the alloys with high content of $\gamma^{\prime}$-phase $(92-95 \%)$ are referred to the hardto-weld class due to a risk of crack initiation.

At present, for brazing the high-temperature high-alloy nickel alloys the brazing filler alloys (BFA) $\left(\mathrm{Ni}-\mathrm{Cr}-\mathrm{Si}-\mathrm{B}, \mathrm{Ni}-\mathrm{Cr}-\mathrm{Co}^{-} \mathrm{B}, \mathrm{Ni}-\mathrm{W}-\mathrm{CO}^{-}\right.$ $\mathrm{B}, \mathrm{Ni}-\mathrm{Cr}-\mathrm{Al}-\mathrm{B}, \mathrm{Ni}-\mathrm{Cr}-\mathrm{Al}-\mathrm{Si}-\mathrm{B}$ and $\mathrm{Ni}-\mathrm{Si}-\mathrm{B}$ ) are used, in which silicon and boron play the role of depressants. They lead to formation of brittle phases in joints (silicides and borides), the elimination of which is connected with long-term process of heat treatment or almost not possible in practice. The presence of borides in brazed joints is not desirable due to their negative effect on fatigue life. Examples of application of BFA of $\mathrm{Ni}-\mathrm{Cr}-\mathrm{Fe}-\mathrm{Si}-\mathrm{B}$ (MBF20) and $\mathrm{Ni}-\mathrm{Co}-\mathrm{Ti}-\mathrm{Zr}$ systems are given in works $[6,7]$.

In the given work the microstructural features of joints of intermetallic alloys on $\gamma^{\prime}$-phase base $\left(\mathrm{Ni}_{3} \mathrm{Al}\right)$, made by high-temperature vacuum brazing using an industrial BFA VPr27 $\left(\mathrm{Ni}-\mathrm{Co}^{-} \mathrm{Cr}-\right.$ $\mathrm{W}-\mathrm{Mo}-\mathrm{Al}-\mathrm{Nb}-\mathrm{B})$ and experimental $\mathrm{BFA}$ of $\mathrm{Ni}-$ $\mathrm{Cr}-\mathrm{Zr}$ system are consitered.

To perform the experiments, intermetallic nickel alloys of two compositions (wt.\%: $\mathrm{Ni}-14 \mathrm{Al}$ and $\left.\mathrm{Ni}-14 \mathrm{Al}-5 \mathrm{Mo}^{-}-4 \mathrm{Co}-2.5 \mathrm{~W}\right)$, as well as $\mathrm{Ni}-$ $\mathrm{Cr}-\mathrm{Zr}$ BFA were melted. Melting was performed by electric arc method with argon blowing on cold substrate with a five-fold turning over and remelting. The produced ingots had a drop-like shape (Figure 1, $a$ ). Method of induction remelting was also used with ingot formation in sectional cooled mould (Figure 1, $b$ ). In some cases the metal melt was drawing into $4 \mathrm{~mm}$ diameter quartz tube using vacuum. The produced rods of 10-15 mm length and $4 \mathrm{~mm}$ diameter were expended into washers of $1.2 \mathrm{~mm}$ height and 


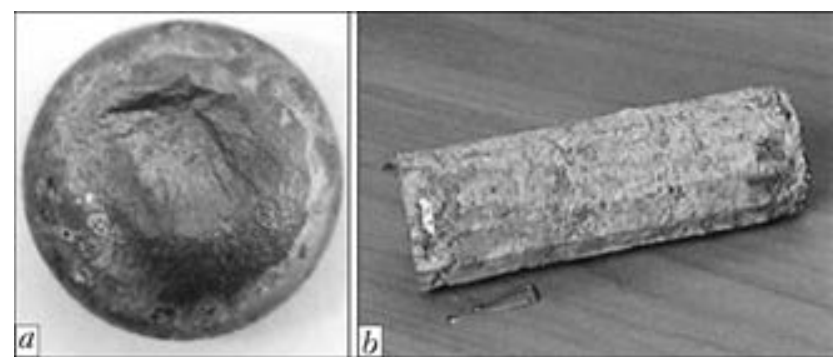

Figure 1. Appearance of experimental ingots melted by using arc $(a)$ and induction $(b)$ heating

cleaned by abrasive paper. Such plates were used for experiments on BFA spreading of and optimizing the technological process brazing.

The specimens were assembled by using resistance welding machine, then they were brazed in vacuum $1.33 \cdot 10^{-4} \mathrm{~Pa}$ by use of radiation heating. Heating temperature was controlled by two thermocouples: main one located in furnace, and auxiliary one located next to specimens ( $\mathrm{Fi}$ gure 2).

To determine the contact angle of wetting the experiments were carried out on BFA spreading according to non-standard procedure: BFA preforms in cast form were placed in the middle of melted intermetallic alloys, fixed by resistance welding and loaded into furnace. For statistics, three specimens with each BFA were loaded for one charge, they were mounted on ceramic substrate in furnace together with thermocouple and heated. The brazed joints were examined using optic (Neophot-32) and scanning electron (Tescan MIRA 3 LMU) microscopy, X-ray spectral microanalyses were carried out in energy-dispersed spectrometer Oxford Instruments X-MAX 80 with program package INCA.

The results of experiments showed that at $T_{\mathrm{b}}=$ $=1200{ }^{\circ} \mathrm{C}, \tau=5$ min the $\mathrm{Ni}-\mathrm{Cr}-\mathrm{Zr}$ BFA has a good spreading over $\mathrm{Ni}-\mathrm{Al}$ substrate, spread drop solidification occurs with the formation of clean surface (Figure 3, $a$ ). The given BFA is referred to eutectic alloy, characterized by a narrow interval of solidification $\left(T_{\mathrm{S}}=1175{ }^{\circ} \mathrm{C}, T_{\mathrm{L}}=\right.$ $=1200{ }^{\circ} \mathrm{C}$ ), that has a positive influence on its spreading ability. Industrial BFA $\operatorname{VPr} 27\left(T_{\mathrm{S}}=\right.$

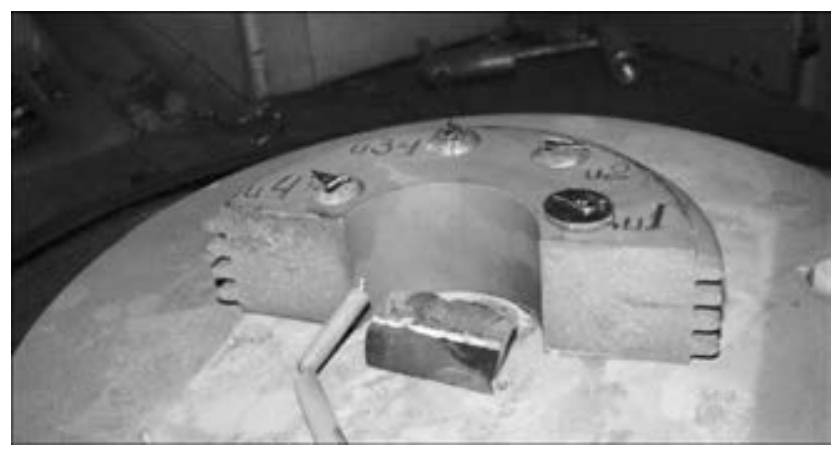

Figure 2. Appearance of specimens prepared for brazing

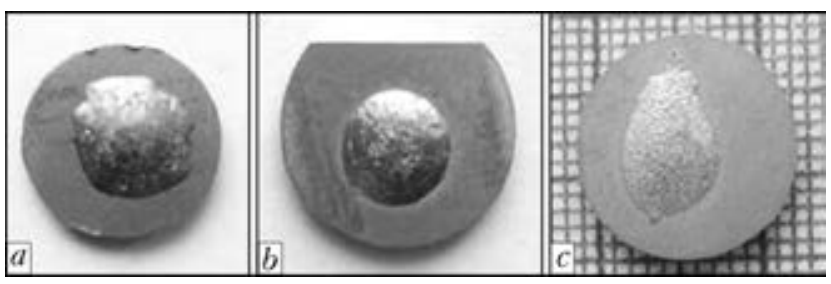

Figure 3. Spreading at $T_{\mathrm{b}}=1200{ }^{\circ} \mathrm{C}$ of experimental $\mathrm{Ni}-$ $\mathrm{Cr}-\mathrm{Zr}$ BFA over $\mathrm{Ni}-\mathrm{Al}(\tau=5 \mathrm{~min})(a)$ and $\mathrm{Ni}-\mathrm{Al}-\mathrm{Mo}-$ $\mathrm{Co}-\mathrm{W}(\tau=15 \mathrm{~min})(b)$ substrate and industrial BFA VPr27 over $\mathrm{Ni}-\mathrm{Al}-\mathrm{Mo}-\mathrm{Co}^{-} \mathrm{W}$ substrate $(\tau=15 \mathrm{~min})(c)$

$=1030{ }^{\circ} \mathrm{C}, T_{\mathrm{L}}=1080{ }^{\circ} \mathrm{C}$ ) also provided a good wetting of surface of $\mathrm{Ni}-\mathrm{Al}-\mathrm{Mo}^{-} \mathrm{Co}^{-} \mathrm{W}$ intermetallic alloy (Figure 3,c).

To determine the contact angle of wetting, which is one of main factors in study of BFA spreading, the specimens after BFA melting were cut normal to the base material plane (plate), microsections were manufactured, contact angle, formed by surface of BFA drop and base metal, was measured, and then the metallographic examinations and $\mathrm{X}$-ray spectral microanalysis were made. The obtained results showed that in use of industrial BFA VPr27 the contact angle is $12^{\circ}$ (Figure 4, $a$ ), while in applying of experimental $\mathrm{Ni}-\mathrm{Cr}-\mathrm{Zr}$ BFA it is decreased to $6^{\circ}$ (Figure 4, $b)$, that confirms its better spreading ability.

The X-ray spectral microanalysis revealed the erosion of base metal and zonal liquation at the interface between BFA VPr27 and intermetallic alloy with formation of two zones, different in chemical composition (Figure 5, Table 1). The enrichment of BFA metal, adjacent to base metal,

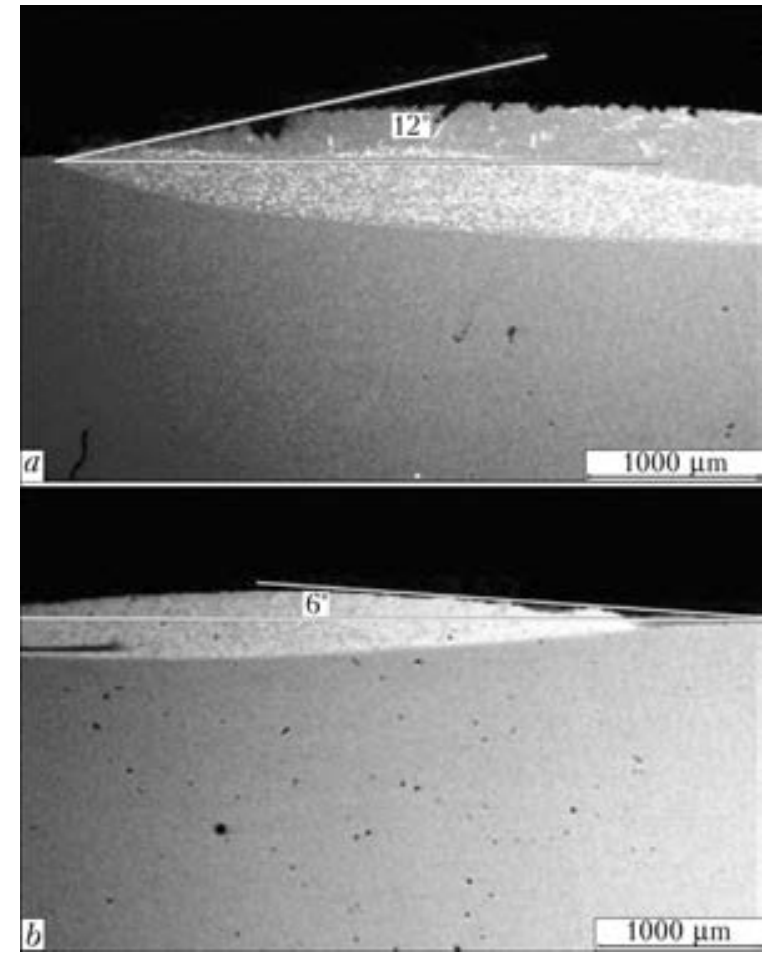

Figure 4. Microstructure of molten $\operatorname{VPr} 27$ ( $a$ ) and $\mathrm{Ni}-\mathrm{Cr}-\mathrm{Zr}$ (b) BFA on intermetallic substrate 


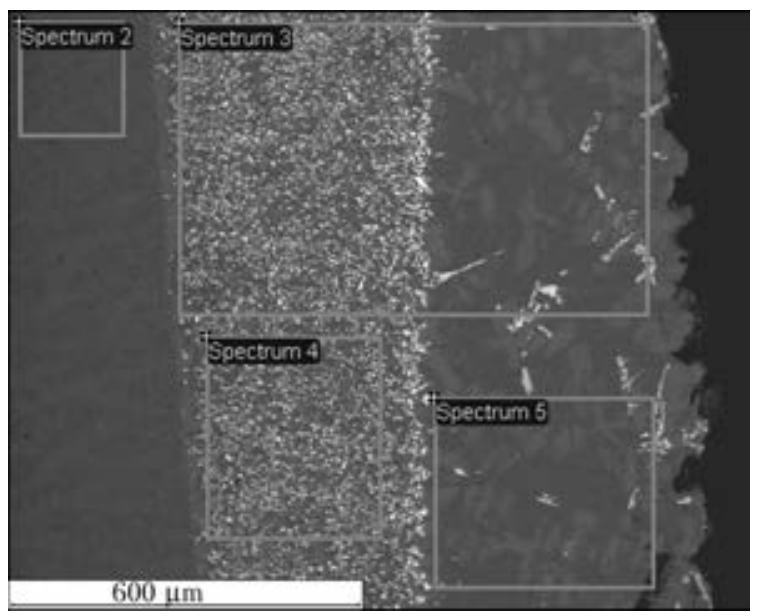

Figure 5. Microstructure and zonal liquation in examining regions in spreading of BFA VPr27 over $\mathrm{Ni}-\mathrm{Al}-\mathrm{Co}^{-} \mathrm{W}$ substrate

with tungsten (up to $14.19 \%$ ) and molybdenum $(4.59 \%)$ was also found. Diffusion of aluminium from base metal into molten BFA was observed, resulting in its concentration amounted to $3.97 \%$, in the zone, adjacent to base metal, and in the upper BFA (external) zone it increased up to $5.16 \%$. Concentration of the rest elements was differed negligibly (see Table 1).

To reduce the erosion of base metal, brazing of as-cast nickel aluminides by powdered BFA VPr27 was performed at the lower temperature $\left(1170{ }^{\circ} \mathrm{C}\right)$ during $3 \mathrm{~min}$. The brazed joints of $\mathrm{Ni}-\mathrm{Al}$ binary alloy were formed with full fillets, in which the liquation processes were observed (Figure 6). Structure of fillet regions is greatly differed from the structure of brazed seams both by the morphological constitution and also by chemical composition. On the background of matrix of solid solution on nickel base the complex intermetallic phases are distinguished, enriched with tungsten (up to 56), molybdenum (up to 9), cobalt (up to 5) and nickel (up to 15 wt.\%), which are solidified mainly in the zone adjacent to base metal. Moreover, the single inclusions of $\mathrm{Cr}-30 \mathrm{Ni}-8 \mathrm{~W}-4 \mathrm{Mo}-5 \mathrm{Co}$ (wt.\%) are observed.

The brazed seams are also characterized by chemical inhomogeneity. The regions are observed, in which phase $\mathrm{Cr}-14 \mathrm{Ni}-19 \mathrm{~W}-8 \mathrm{Mo}^{-}$ $6 \mathrm{Co}-0.7 \mathrm{Nb}$ (wt.\%) is formed in the seam centre.
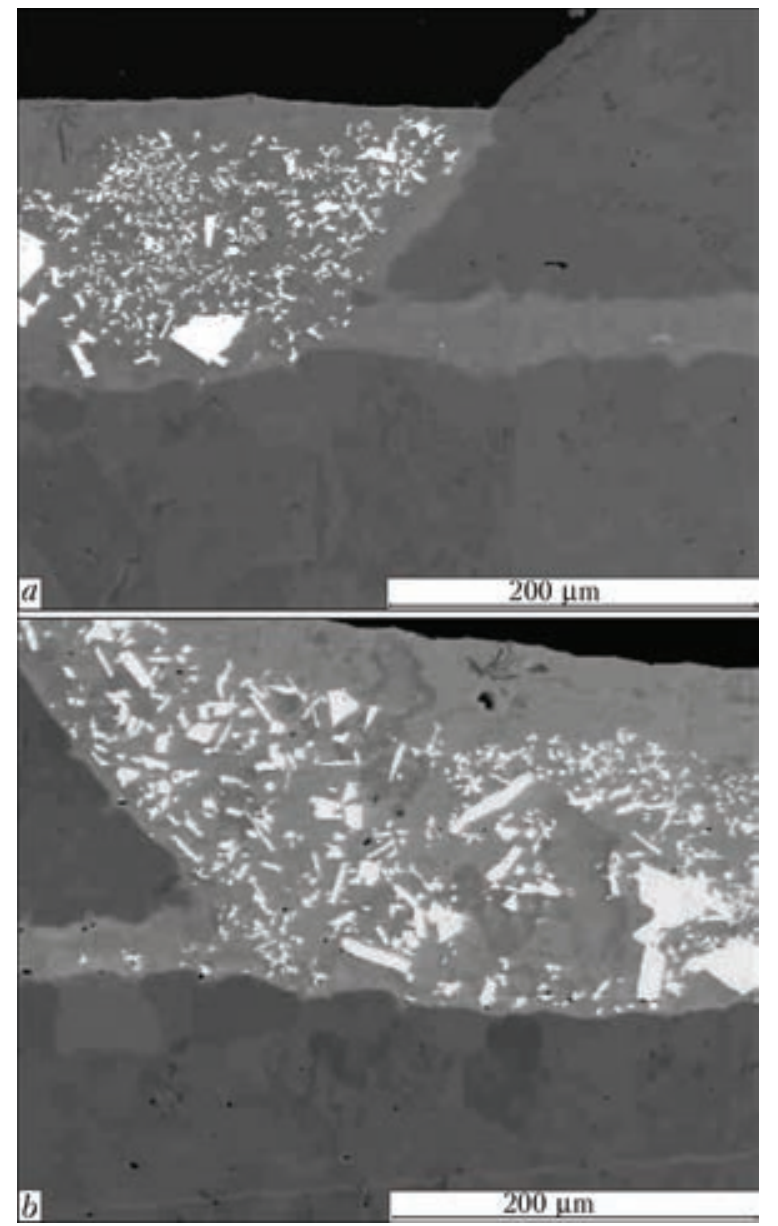

Figure 6. Joints of $\mathrm{Ni}-\mathrm{Al}$ alloy made by $\mathrm{BFA} \mathrm{VPr} 27$ in the state after brazing $(a)$ and heat treatment at $1050{ }^{\circ} \mathrm{C}$ for $30 \min (b)$

In some regions it is precipitated in the form of separate light grains. Single pores are also observed (Figure 7). Grey matrix of seam, i.e. the zone adjacent to material being brazed, is a solid solution on nickel base, containing about 7 wt.\% $\mathrm{Al}$ and other elements in negligible amount. In the near-seam zone of base metal on nickel base the X-ray spectral microanalysis showed, except 13 wt.\% Al, the presence of negligible amount of BFA alloying elements, wt.\%: 0.24 Mo; $0.40 \mathrm{~W} ; 0.24 \mathrm{Nb}$. Heat treatment at $1050{ }^{\circ} \mathrm{C}$ for $30 \mathrm{~min}$ had no influence on structure of brazed joints, the amount of composed phases and their size remained without changes (see Figure 6, $b$ ).

Table 1. Distribution of elements in examining regions during spreading of industrial BFA VPr27 over $\mathrm{Ni}^{-} \mathrm{Al}-\mathrm{Mo}-\mathrm{Co}-\mathrm{W}$ alloy

\begin{tabular}{|c|c|c|c|c|c|c|c|c|}
\hline \multirow{2}{*}{$\begin{array}{l}\text { Number of } \\
\text { spectrum (see } \\
\text { Figure 5) }\end{array}$} & \multicolumn{8}{|c|}{ Composition, wt.\% } \\
\hline & $\mathrm{Al}$ & $\mathrm{Cr}$ & $\mathrm{Fe}$ & Co & $\mathrm{Ni}$ & $\mathrm{Nb}$ & Mo & W \\
\hline 2 & 10.03 & - & - & 4.85 & 76.42 & - & 6.11 & 2.59 \\
\hline 3 & 4.17 & 5.24 & 0.26 & 8.04 & 66.99 & 1.25 & 3.32 & 10.73 \\
\hline 4 & 3.97 & 5.12 & 0.31 & 7.52 & 63.37 & 0.93 & 4.59 & 14.19 \\
\hline 5 & 5.16 & 5.48 & 0.18 & 8.53 & 74.07 & 1.03 & 1.97 & 3.57 \\
\hline
\end{tabular}




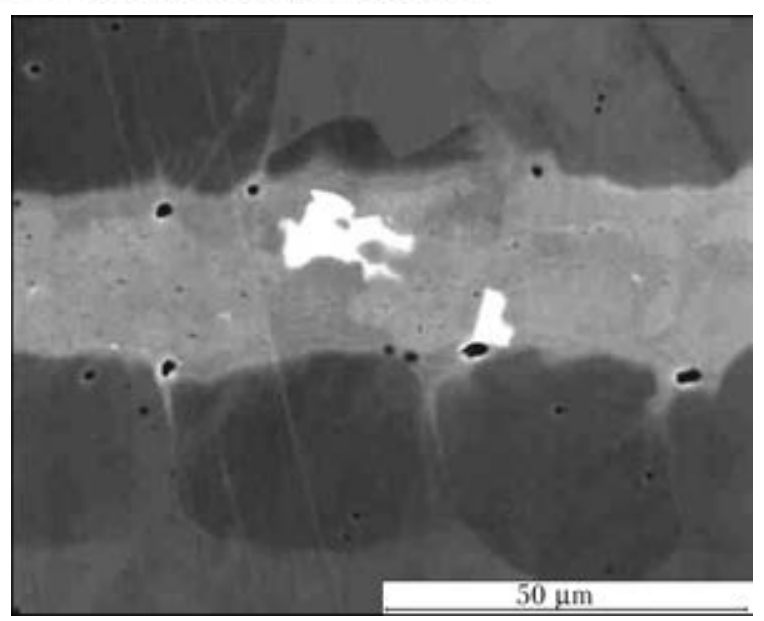

Figure 7. Microstructure of brazed seam on nickel aluminide made by BFA VPr27

Brazing at the same condition of alloy $\mathrm{Ni}-\mathrm{Al}-$ $\mathrm{Mo}^{-} \mathrm{Co}^{-} \mathrm{W}$, alloyed with refractory elements, differed by another formation of structure both in fillet regions and also in seams (Figure 8). Judging from results of X-ray spectral microanalysis, the seam matrix is the Ni-based solid solution alloyed by $\mathrm{Al}$ (7), Cr (5), Co (8), Mo (1), W (2). Phase of complex W-based composition, enriched by Mo (22), Ni (27), Cr (6\%), is pre-
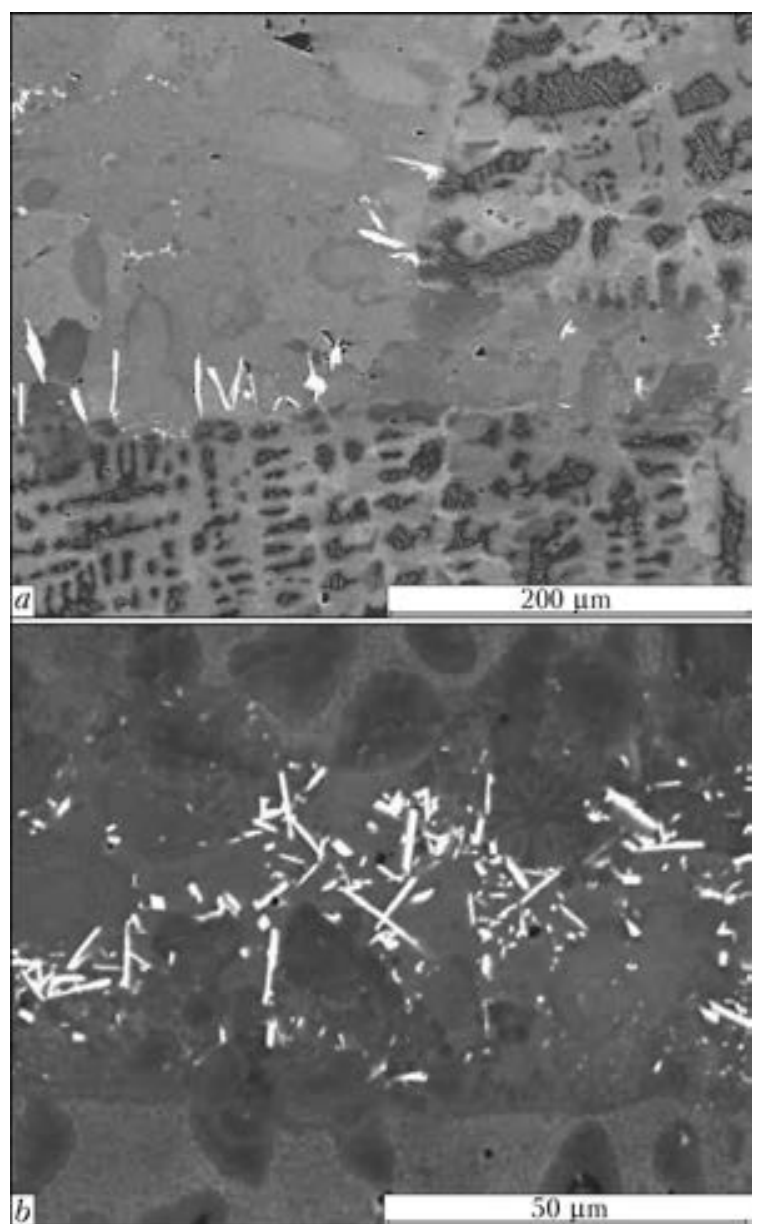

Figure 8. Structure of $\mathrm{Ni}-\mathrm{Al}-\mathrm{Mo}_{-}-\mathrm{Co}_{-}-\mathrm{W}$ alloy joint made by BFA VPr27 at $T_{\mathrm{b}}=1170{ }^{\circ} \mathrm{C}, \tau=3 \mathrm{~min}: a-$ fillet region; $b$ - brazed seam
Table 2. Distribution of elements in examining regions of brazed joint of $\mathrm{Ni}-\mathrm{Al}$ alloy in applying of $\mathrm{Ni}-\mathrm{Cr}-\mathrm{Zr} \mathrm{BFA}$

\begin{tabular}{|c|c|c|c|c||}
\hline \multirow{2}{*}{$\begin{array}{c}\text { Number of } \\
\text { spectrum } \\
\text { (see } \\
\text { Figure 9) }\end{array}$} & $\mathrm{Al}$ & $\mathrm{Cr}$ & $\mathrm{Ni}$ & $\mathrm{Zr}$ \\
\cline { 2 - 5 } & 11.67 & - & 88.33 & - \\
\hline 2 & 8.45 & 0.54 & 91.01 & - \\
\hline 3 & 0.40 & 4.97 & 82.31 & 12.32 \\
\hline 4 & 0.37 & 3.23 & 80.06 & 16.34 \\
\hline 5 & 0.45 & 8.49 & 90.37 & 0.69 \\
\hline 6 & 0.11 & 0.85 & 74.11 & 24.93 \\
\hline 7 & - & 1.18 & 19.47 & 79.34 \\
\hline 8 & \multicolumn{5}{|c}{} \\
\hline
\end{tabular}

cipitated in the form of dispersed needle-like particles. Mass share of aluminium in these particles is decreased to $0.4 \%$. As to the morphological constitution this phase can be referred to the intermetallic compound on the base of refractory elements due to typical proper geometry peculiar to them (Figure 8). In the fillet region this phase occupies a rather low percent of the area $(\sim 1 \%)$ as compared to the seam. The main structural component is the solid solution on $\mathrm{Ni}$ base (76\%), containing also such hardening alloying elements as $\mathrm{Cr}(6), \mathrm{Co}(8), \mathrm{Al}(4 \%)$ and negligible share (by $\sim 1.5 \%$ ) of rest elements, such as $\mathrm{Nb}, \mathrm{Mo}$ and $\mathrm{W}$.

The carried out investigations showed that the morphological constitution of brazed joints is affected not only by temperature-time parameters of technological process of brazing, but also by chemical composition of material being brazed. Thus, in use of alloyed $\mathrm{Ni}-14 \mathrm{Al}-5 \mathrm{Mo}^{-}-4 \mathrm{Co}-2.5 \mathrm{~W}$ alloy as a base material the precipitates of $\mathrm{W}$ enriched phase are observed in the form of dispersed needle-like particles of 1.5-2.0 $\mu \mathrm{m}$ width both in fillet region and also in brazed seam (see

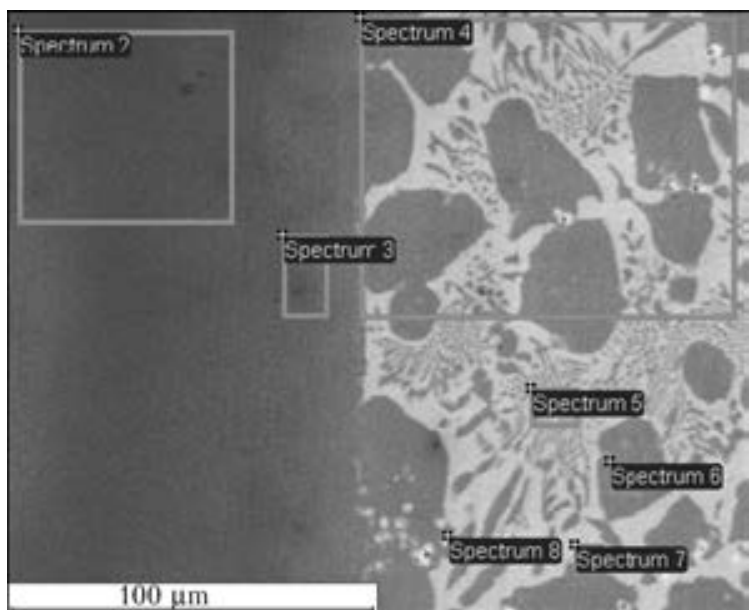

Figure 9. Microstructure of $\mathrm{Ni}-\mathrm{Al}$ alloy $/ \mathrm{Ni}-\mathrm{Cr}-\mathrm{Zr}$ BFA interface 
$T,{ }^{\circ} \mathrm{C}$

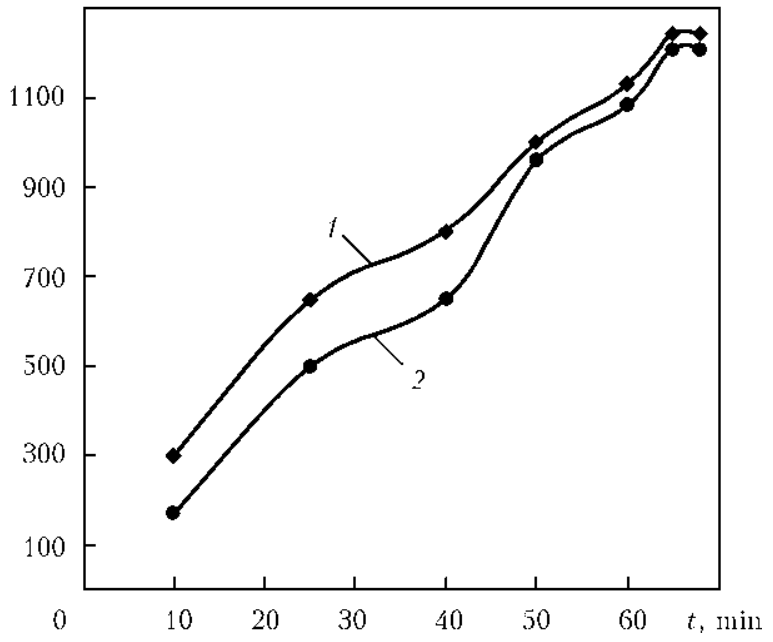

Figure 10. Thermogram in brazing by $\mathrm{Ni}-\mathrm{Cr}-\mathrm{Zr} \mathrm{BFA}$ at $T_{\mathrm{b}}=1170{ }^{\circ} \mathrm{C}, \tau=3$ min: 1 - thermocouple in chamber; 2 - on specimen

Figure 8 ). In brazing of binary $\mathrm{Ni}-14 \mathrm{Al}$ alloy the phase, enriched by tungsten, is precipitated in the form of rather coarse inclusions. In the fillet region their size is about $40 \mu \mathrm{m}$, in seam it is about $18 \mu \mathrm{m}$.

In addition, microstructure of molten BFA on intermetallic substrate is differed from that of brazed seam. This can be explained by the effect of geometric parameters (capillary gaps, length of base metal-BFA interface), as well as BFA amount on the proceeding of diffusion processes during heating. In spreading of $\mathrm{Ni}-\mathrm{Cr}-\mathrm{Zr} \mathrm{BFA}$ over the substrate of binary $\mathrm{Ni}-\mathrm{Al}$ alloy the zonal solidification is absent (see Figure $4 b$; Figure 9). The molten BFA is solidified in the form of eutectic alloy formed by primary grains of solid solution on nickel base and intermetallic, containing up to $25 \% \mathrm{Zr}$ (see Figure 9, Table 2). Negligible amount of single dispersed precipitates of phase on zirconium $(79.34 \%$ ) base is observed. Aluminium is not almost diffused into the molten BFA, that is confirmed by the results of X-ray spectral microanalysis.

Vacuum brazing of butt joints with $\mathrm{Ni}-\mathrm{Cr}-\mathrm{Zr}$ BFA was carried out at $1210^{\circ} \mathrm{C}$ for 3 min holding. The temperature mode of brazing was recorded in the form of thermogram (Figure 10). In brazing of $\mathrm{Ni}-\mathrm{Al}$ alloy and alloyed $\mathrm{Ni}-\mathrm{Al}-\mathrm{Mo}^{-} \mathrm{Co}^{-} \mathrm{W}$ alloy the BFA of $\mathrm{Ni}-\mathrm{Cr}-\mathrm{Zr}$ system is melted, material being brazed is wetted, and flow into capillary gap and to the reverse side of specimen with formation of full dense fillets (Figure 11), thus being the confirmation of good fluidity of the eutectic BFA.

After brazing the experimental specimens were cut into plates for further investigations. Metallographic examinations of brazed joints of intermetallic alloy $\mathrm{Ni}-14 \mathrm{Al}$ showed that $\mathrm{Ni}-\mathrm{Cr}-$

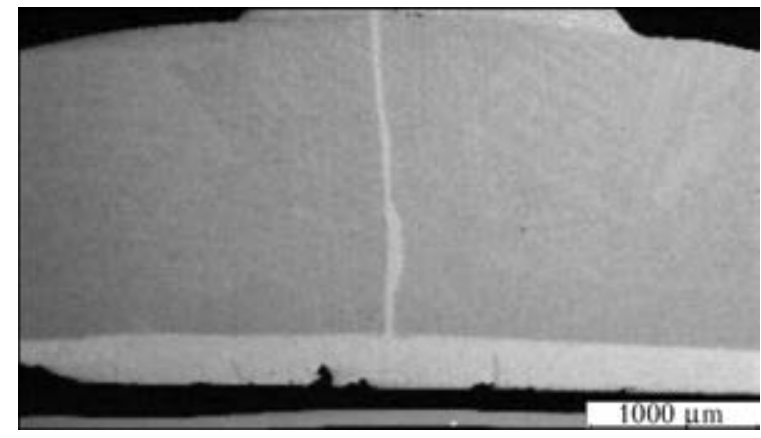

Figure 11. Macrosection of butt joint of $\mathrm{Ni}-\mathrm{Al}$ alloy made by $\mathrm{Ni}-\mathrm{Cr}-\mathrm{Zr}$ BFA

Zr BFA can form sound seams of variable width from 30 up to $50 \mu \mathrm{m}$. In the seam central zone the Ni-based eutectic phase, enriched with zirconium up to 7 wt.\%, is solidified in the form of a thread-like band of $5 \mu \mathrm{m}$ width. At the joint boundary the zone of common grains of base metal is observed, where the seam in its classical conception is absent (Figure 12, $b$ ). It should be noted that concentration of zirconium in the dark part of seam does not exceed 0.49 wt.\%, while aluminium concentration reaches 7 wt.\%, that proves the proceeding of diffusion processes at the interface. X-ray spectral microanalysis determined that eutectics was formed by solid solution on nickel base and intermetallic phase, enriched with zirconium up to $21 \%$ (Table 3, Figure 13).

After heat treatment of brazed joints at $1150{ }^{\circ} \mathrm{C}$ for $30 \mathrm{~min}$ the seam width was $32 \mu \mathrm{m}$.
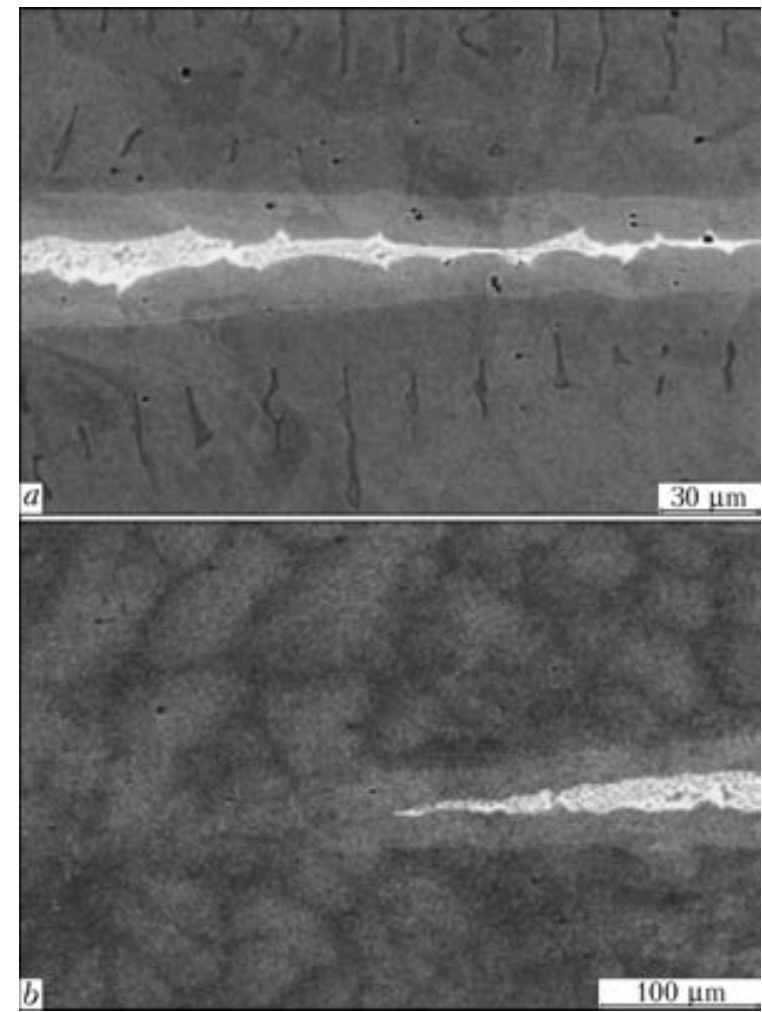

Figure 12. Microstructure of brazed seam on $\mathrm{Ni}-\mathrm{Al}$ alloy made by $\mathrm{Ni}-\mathrm{Cr}-\mathrm{Zr}$ BFA $(a)$, and zone of common grains of base metal $(b)$ 
SCIENTIFIC AND TECHNICAL

Table 3. Distribution of elements in examining regions of brazed joint of $\mathrm{Ni}-\mathrm{Al}$ alloy made by $\mathrm{Ni}-\mathrm{Cr}-\mathrm{Zr} \mathrm{BFA}$

\begin{tabular}{|c|c|c|c|c|c|c|c|}
\hline \multirow{2}{*}{$\begin{array}{l}\text { Number of } \\
\text { spectrum (see } \\
\text { Figure 13) }\end{array}$} & \multicolumn{7}{|c|}{ Composition, wt.\% } \\
\hline & $\mathrm{Al}$ & $\mathrm{Cr}$ & Co & $\mathrm{Ni}$ & $\mathrm{Zr}$ & Mo & $\mathrm{W}$ \\
\hline 2 & 8.57 & - & 4.76 & 78.13 & - & 5.52 & 3.02 \\
\hline 3 & 4.61 & 3.05 & 3.10 & 83.10 & - & 3.39 & 2.75 \\
\hline 4 & 0.47 & 4.45 & 0.11 & 79.72 & 14.60 & - & 0.64 \\
\hline 5 & 0.34 & 2.22 & 0.16 & 76.30 & 20.98 & - & - \\
\hline 6 & 0.42 & 4.58 & 0.41 & 78.50 & 15.26 & - & 0.83 \\
\hline 7 & 0.46 & 4.33 & 0.19 & 79.34 & 14.93 & - & 0.75 \\
\hline
\end{tabular}

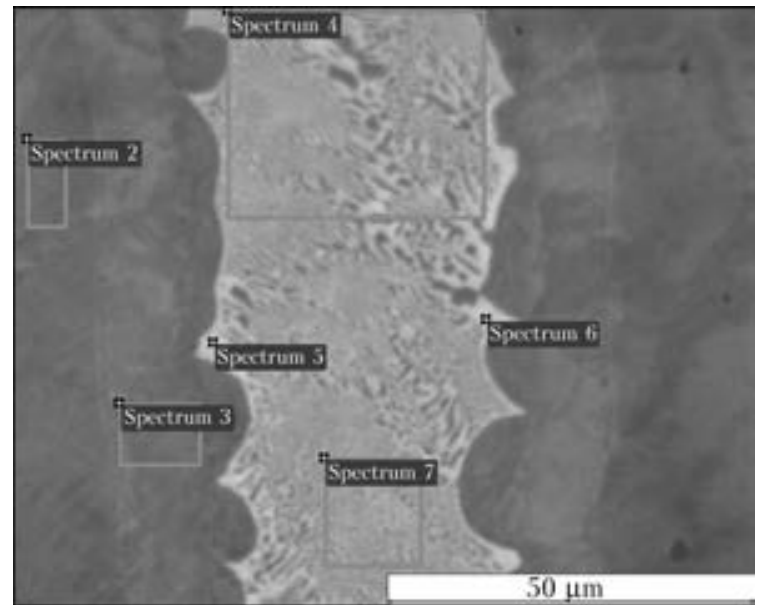

Figure 13. Regions of local microanalysis after brazing of $\mathrm{Ni}-\mathrm{Al}$ alloy by $\mathrm{Ni}-\mathrm{Cr}-\mathrm{Zr} \mathrm{BFA}$

Composition of intermetallic phase, which is solidified in seam centre, is somewhat changed: on the background of light phase of zirconium intermetallic, containing 20-23 wt.\% $\mathrm{Zr}$, the second phase is formed in the form of globules of dark color of about $1.5 \mu \mathrm{m}$ size, which contains 13-15 wt.\% Zr. Precipitates of dark phase (solid solution) in some seam regions has a continuous nature, their composition corresponds to compound $87.66 \mathrm{Ni}-6.76 \mathrm{Al}-4.59 \mathrm{Cr}-0.99 \mathrm{Zr}$.

The seam zone, adjacent directly to base metal, contains about (wt.\%) $1 \mathrm{Zr}, 6-7 \mathrm{Al}, 4 \mathrm{Cr}$. After 30 min holding at $1150{ }^{\circ} \mathrm{C}$ due to diffusion processes between the material being brazed and

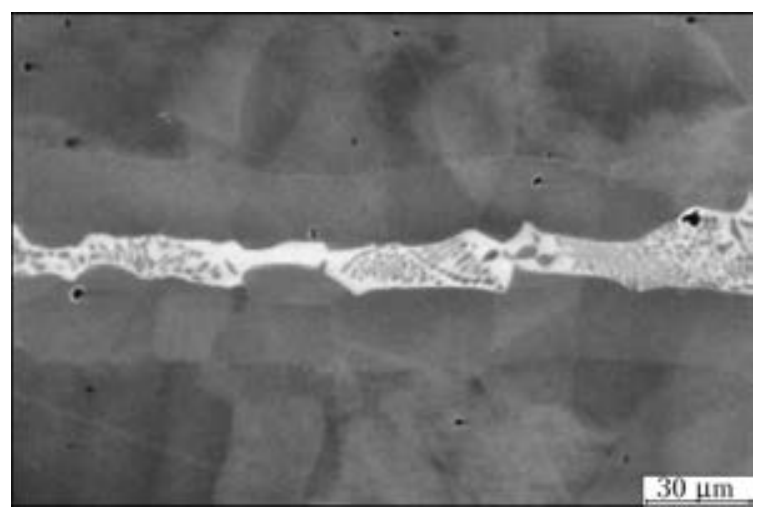

Figure 14. Eutectic structure of brazed seam $(\mathrm{Ni}-\mathrm{Al}$ alloy, $\mathrm{Ni}-\mathrm{Cr}-\mathrm{Zr}$ BFA) after heat treatment at $1150{ }^{\circ} \mathrm{C}$ for $30 \mathrm{~min}$
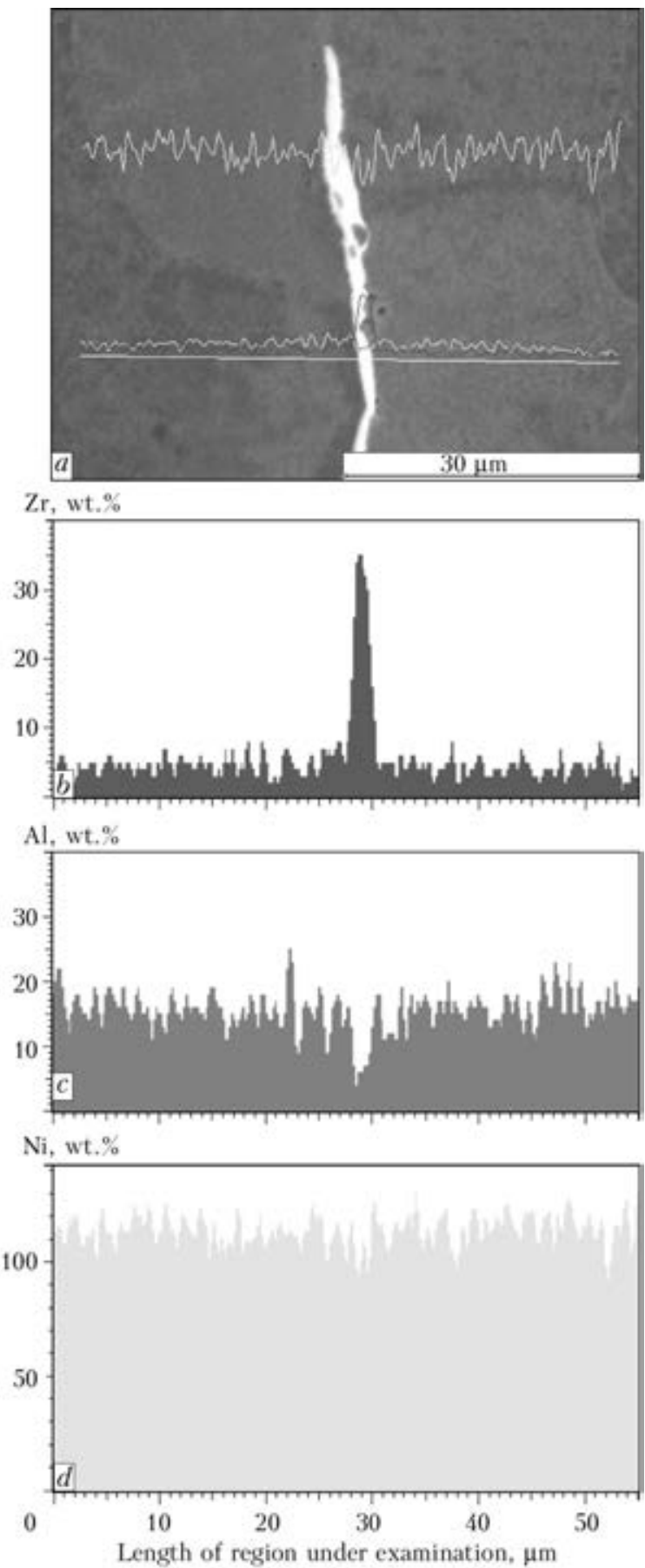

Figure 15. Microstructure $(a)$ and distribution of zirconium $(b)$, aluminium $(c)$ and nickel $(d)$ in brazed seam $(\mathrm{Ni}-\mathrm{Al}$ alloy, $\mathrm{Ni}-\mathrm{Cr}-\mathrm{Zr} \mathrm{BFA}$ ) 
seam metal the concentration of chromium and zirconium is increased in the latter by approximately $1 \mathrm{wt} . \%$. In seams the eutectic structure is retained (Figure 14). The increase in time of holding up to 60 min did not show any effect on structure of seams: in central part the Zr-enriched eutectic is solidified; concentration of aluminium is reduced negligibly, and nickel concentration is not changed.

The conclusion was made on the basis of carried out investigations that eutectic $\mathrm{BFA}$ of $\mathrm{Ni}^{-}$ $\mathrm{Cr}-\mathrm{Zr}$ system have a good spreading over the nickel aluminide (contact angle of wetting is $6^{\circ}$ ), flow into vertical capillary gaps and form the sound seams with eutectic structure. In specimen length the rather homogeneous seam regions are formed, in which the interlocking grains of base metal are observed.

Metallographic examinations are the intermediate stage in the BFA development. The works of the next stage will include the determination of mechanical properties of brazed joints.
1. Grinberg, B.A., Ivanov, M.A. (2002) Ni3Al intermetallics: Microstructure, deformation behavior. Ekaterinburg.

2. Povarova, K.B., Kazanskaya, N.K., Buntushkin, V.P. et al. (2003) Thermostability of structure of alloy based on $\mathrm{Ni} 3 \mathrm{Al}$ and its application in blades of smallsized gas turbine engines. Metally, 3, 95-100.

3. Buntushkin, V.P., Kablov, E.N., Bazyleva, O.A. et al. (1999) Alloys based on nickel aluminides. $\mathrm{Mi}^{-}$ TOM, 1, 32-34.

4. Buntushkin, V.P., Bronfin, M.B., Bazyleva, O.A. et al. (2004) Influence of alloying and structure of castings on heat resistance of Ni3Al intermetallics at high temperature. Metally, 2, 107-110.

5. Kablov, E.N., Buntushkin, V.P., Povarova, K.B. et al. (1999) Low alloy light heat-resistant high-temperature materials based on $\mathrm{Ni} 3 \mathrm{Al}$ intermetallics. Ibid., 1, 58-65.

6. Khorunov, V.F., Perevezentsev, B.N., Ubirajlo, O.G. (2013) Examination of structure and chemical heterogeneity of joints of intermetallic $\mathrm{Ni}_{3} \mathrm{Al}$ alloy. In: Proc. of Int. Sci.-Techn. Conf. on Brazing, 255-264. Toliatti: TGU.

7. Khorunov, V.F., Maksymova, S.V. (2013) Prospective systems of filler metals for brazing of heat-resistant alloys based on nickel and titanium. Physicaltechnical problems of modern materials science, Vol. 1, 105-134. Kiev: Akademperiodika.

Received 12.03.2014 